\title{
Korelasi kadar glukosa saliva dengan kadar glukosa darah terhadap terjadinya kandidiasis oral pada penderita diabetes melitus (Correlation of salivary glucose level and blood glucose level with oral candidiasis in diabetes mellitus patient)
}

\author{
${ }^{1}$ Sumintarti, ${ }^{2}$ Fildzah Rahman \\ ${ }^{1}$ Departemen Ilmu Penyakit Mulut \\ ${ }^{2}$ Mahasiswa Tahap Profesi \\ Fakultas Kedokteran Gigi Universitas Hasanuddin \\ Makassar, Indonesia
}

\begin{abstract}
Diabetes mellitus (DM) is a disorder of carbohydrate metabolism which characterized by increased blood glucose level, which also increase the salivary glucose level. Glucose is a good medium for the growth of microorganisms including C.albicans. One of the most common infections of the oral mucosa of patients with DM is candidiasis. Chronic candidiasis may develop to be a malignancy. This study aimed to determine the correlation of salivary glucose levels with blood glucose levels to the occurrence of oral candidiasis in patients with DM. Analytic observational study was carried out through the determination of blood glucose levels just by way of strip using a glucometer and salivary glucose levels with "GOD PAP test enzymatic kolometrik". Oral candidiasis was determined in presenting C.albicans on 30 patients with DM with seeding Saboround agar and gram staining. The results showed $r=0.228$, which is higher salivary glucose levels followed by high levels of blood glucose, and microscopic examination of Candida spores found in the whole sample, as well as Candida hyphae on two samples of the study. It was concluded that there is a correlation between salivary glucose levels and blood glucose levels, and glucose levels affect the occurrence of oral candidiasis in patients with DM. Keywords:diabetes mellitus, salivary glucose level, blood glucose level, oral candidiasis
\end{abstract}

\begin{abstract}
ABSTRAK
Diabetes melitus (DM) adalah suatu kelainan akibat gangguan metabolisme karbohidrat yang ditandai dengan peningkatan kadar glukosa darah, yang juga meningkatkan kadar glukosa saliva. Glukosa adalah media yang baik bagi pertumbuhan organisme mikro termasuk C.albicans. Salah satu infeksi yang paling sering mengenai mukosa mulut penderita DM adalah kandidiasis. Kandidiasis kronis dapat berkembang menjadi ganas. Penelitian ini dimaksudkan untuk mengetahui korelasi kadar glukosa saliva dengan kadar glukosa darah terhadap terjadinya kandidiasis oral pada penderita DM. Penelitian observasional analitik ini dilakukan melalui penentuan kadar glukosa darah sesaat dengan cara strip menggunakan alat glukometer dan kadar glukosa saliva dengan "uji GOD PAP enzimatik kolometrik". Kandidiasis oral ditentukan dengan melihat keberadaan C.albicans pada 30 sampel penderita DM dengan pembenihan agar Saboround serta pengecatan gram. Hasil penelitian ini menunjukkan $\mathrm{r}=0,228$, yaitu kadar glukosa saliva yang tinggi diikuti kadar glukosa darah yang tinggi, dan pada pemeriksaan mikroskopis ditemukan spora Candida pada seluruh sampel, serta hifa Candida pada dua sampel penelitian. Disimpulkan bahwa ada hubungan antara kadar glukosa saliva dan kadar glukosa darah, serta peningkatan kadar glukosa mempengaruhi terjadinya kandidiasis oral pada pasien DM.
\end{abstract}

Kata kunci: diabetes melitus, kadar glukosa saliva, kadar glukosa darah kandidiasis oral

Koresponden: Fildzah Rahman.E-mail: fildzahrahman128@gmail.com

\section{PENDAHULUAN}

Diabetes melitus(DM) adalah penyakit endokrin yang ditandai dengan kondisi kekurangan produksi insulin sehingga terjadi perubahan proses asimilasi, metabolisme, dan keseimbangan konsentrasi glukosa darah. ${ }^{1}$

Uji diagnostik pada umumnya menggunakan darah. Akan tetapi, saat ini ketertarikan uji diagnostik telah berkembang pada uji yang non-invasive, yaitu menggunakan saliva, ${ }^{2}$ yang merupakan cairan yang mengandung berbagai zat seperti enzim, hormon, antibodi dan beberapa growth factor, sama seperti darah. Zat-zat tersebut terekspresi dalam saliva dari darah melewati ruang antarsel dengan cara pasif dan aktif. Banyak komponen darah yang ditemukan dalam saliva sehingga sangat berpotensi digunakan dalam deteksi dini penyakit sistemik, sama halnya dengan darah. ${ }^{1-3}$

Glukosa layaknya molekul kecil yang mampu bergerak secara mudah di dalam membran pembuluh darah, yang dapat keluar dari plasma darah menuju ke cairan gingiva melalui sulkus gingiva, selanjutnya mencapai saliva. Peningkatan kadar glukosa darah pada pasien DM mampu menyebabkan kadar glukosa pada saliva menjadi lebih tinggi, yang berdampak pada kehilangan homeostatis dan kerentanan yang lebih besar untuk terjadinya penyakit dalam rongga mulut. ${ }^{4}$ Pada pasien DM yang mengalami peningkatan kadar glukosa darah akan menunjukkan perubahan kondisi rongga mulut, misalnya adalah kandidiasis 
oral. ${ }^{1}$ Kandidiasis oral merupakan infeksi oportunis di rongga mulut yang disebabkan oleh pertumbuhan abnormal Candida albicans. ${ }^{5}$

Penyakit DM adalah salah satu tantangan untuk tenaga medis selama 21 tahun terakhir. Dua aspek kuncipada perawatan DM adalahmenormalkan kadar glukosa darah dan kontrol yang baik. Kedua hal ini bergantung pada kunjungan berkala pada dokter. Oleh sebab itu sangat penting bagi pasien DM untuk mengetahui kadar glukosa darah yang normal sebab mereka mempunyai risiko tinggi selama hidupnya karena komplikasi DM yang dapat memperparah kondisi pasien DM. ${ }^{6}$

Penelitian ini dimaksudkan untuk mengetahui korelasi kadar glukosa saliva dengan kadar glukosa pada darah terhadap terjadinya kandidiasis oral pada penderita DM.

\section{BAHAN DAN METODE}

Sampel penelitian sebanyak 30 penderita DM adalah pasien rawat inap di Rumah Sakit Wahidin Sudirohusodo, Rumah Sakit Ibnu Sina,Rumah Sakit Umum Daerah Makassar dengan kriteria yang telah ditentukan.

Sampel saliva diambil pada pagi hari, sekitar jam 8-10 pagi, dengan menggunakan metode spitting. Sebelum dan selama pengumpulan saliva, selama kurun waktu 90 menit sebelum pengumpulan saliva, pasien tidak diperkenankan makan, minum maupun membersihkan rongga mulutnya. Selain itu, pasien tidak diperkenankan bicara, menggerakan lidah, atau melakukan gerakan penelanan. Pasien duduk dengan nyaman dengan sandaran tegak, kepala ditundukkan serta tangan kanan memegang tabung pengumpul saliva.Pengumpulan saliva dilakukan selama 5 menit dengan setiap interval 1 menit pasien diminta untuk mengeluarkan saliva yang terkumpul dalam mulut ke dalam tabung pengukur saliva. Saliva yang telah dikumpulkan kemudian dibawa ke Laboratorium Biokimia untuk diuji kadar glukosa salivanya yang ditentukan dengan menggunakan metode "enzimatik kolometrik GOD-PAP”.

Sampel darah didapatkan dengan menusukkan jarum steril ke ujung jari pasien yang sebelumnya telah dibersihkan dengan menggunakan alkohol $70 \%$. Selanjutnya sampel darah tersebut disimpan pada glucose test strip yang kemudian dimasukkan pada glukometer. Sedangkan pembacaan kadar glukosa darahnya dilakukan dengan menggunakan piranti glukometer dalam satuan $\mathrm{mg} / \mathrm{dL}$.

Sampel kandidiasis oral diperoleh dengan cara melakukan hapusan pada lesi yang ditemukan dalam rongga mulut pasien. Selanjutnya, hasil hapusan lesi tersebut dibawa ke Laboratorium Mikrobiologi untuk dilakukan kultur dengan melakukan pembenihan agar saboround serta pengecatan gram.

\section{HASIL}

Berdasarkan penelitian mengenai kadar glukosa saliva dengan kadar glukosadarah terhadap terjadinya penyakit kandidiasis oral pada penderita diabetes melitus, diperoleh hubungan kadar glukosa saliva dan kadar glukosa darah (tabel 1) $\mathrm{r}=0.288$, yaitu kadar glukosa saliva yang tinggi diikuti oleh kadar glukosa darah yang tinggi.

Tabel 1 Hubungan kadar glukosa darah dengan kadar glukosa saliva

\begin{tabular}{llcc}
\hline & & Darah & Saliva \\
\hline Darah & Pearson Correlation & 1 & 0,288 \\
& Sig. (2-tailed) & & 0,123 \\
& N & 30 & 30 \\
\hline Saliva & Pearson Correlation & 0,288 & 1 \\
& Sig. (2-tailed) & 0,123 & \\
& N & 30 & 30 \\
\hline
\end{tabular}

Pada gambar 1 terlihat bahwa kedua variabel searah, yaitu kadar glukosa darah yang tinggi diikuti kadar glukosa saliva yang tinggi, hingga 151-358 $\mathrm{mg} / \mathrm{dL}$. Sedangkan kadar glukosa saliva antara 0,95 $45,28 \mathrm{mg} / \mathrm{dL}$.

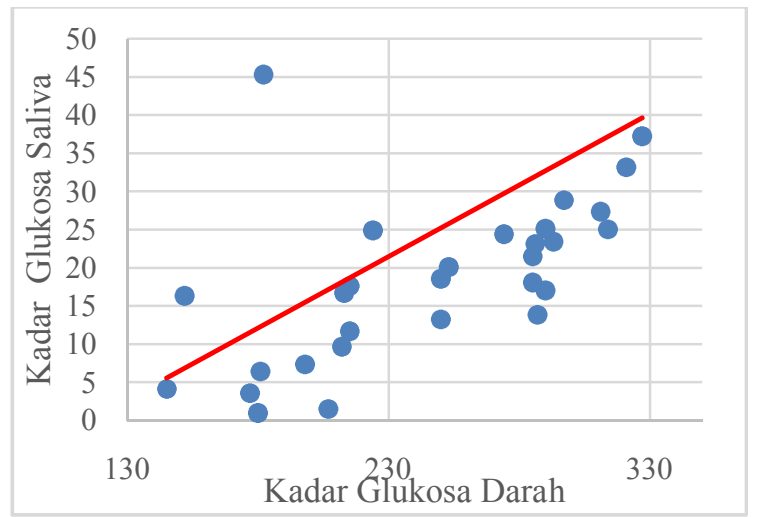

Gambar 1 Grafik hubungan variabel kadar glukosa darah dan kadar glukosa saliva

Berdasarkan tabel 2 tampak ada spora Candida pada seluruh sampel yang diteliti serta adanya hifa Candida pada dua sampel, tetapi tidak demikian pada sampel yang lain.

Tabel 2 Distribusi spora dan hifa

\begin{tabular}{ccc}
\hline & Spora & Hifa \\
\hline Ya & $30(100,0)$ & $2(6,7)$ \\
Tidak & - & $28(93,3)$ \\
\hline Total & $30(100,0)$ & $30(100,0)$ \\
\hline
\end{tabular}

\section{PEMBAHASAN}

Berdasarkan analisis data kadar glukosa darah dan kadar glukosa saliva menggunakan uji statistik, 
didapatkan hasil $r=0,288$. Hal tersebut menandakan bahwa koefisien korelasi bernilai positif; yang berarti kedua variabel, yaitu glukosa darah dan glukosa saliva mempunyai hubungan yang searah.

Hasil penelitian ini sesuai dengan beberapa studi sebelumnya yang dilakukan oleh Lasisi dkk, Carda dkk, serta Aydin dan Thorstensson dkk, yang dikutip oleh Preethi dkk, yaitu kadar glukosa saliva akan meningkat seiring dengan peningkatan kadar glukosa darah yang berkontribusi terhadap kerusakan perpindahan membran dasar pada kelenjar. ${ }^{7}$

Penelitian lain yang dilakukan oleh Abikshyeet dkk, menyimpulkan bahwa terdapat korelasi positif antara glukosa saliva dan serum glukosa pada pasien DM. Hal yang sama juga dikemukakan oleh Belazi dkk dalam penelitiannya, sebagaimana dikutip oleh Preethi, menemukan korelasi positif antara glukosa saliva dan serum glukosa. ${ }^{8}$

Menurut hasil riset Qureshi dkk, hiperglikemi yang bersifat persisten juga akan memicu perubahan vaskularisasi mikro pada pembuluh darah terutama perubahan pada membran dasar di kelenjar saliva. Peningkatan perubahan ini yang terjadi dari transpor glukosa di sel duktus kelenjar saliva oleh karenanya memicupeningkatan produksiglukosa dalam saliva. ${ }^{8}$ Menurut Sreedevi dkk, disimpulkan bahwa glukosa merupakan molekul kecil yang mudah berdisfusi melalui membran sel yang semipermeabel. Oleh karenanya glukosa dalam jumlah yang besar dapat ditemukan pada saliva, ketika terjadi peningkatan glukosa darah pada pasien DM. ${ }^{8}$
Kurangnya korelasi antara glukosa saliva dan glukosa plasma diobservasi oleh Marchetti dkk pada kondisi puasa pada pasien dengan DM dan non-DM; terindikasi adanya tingkatan kontrol metabolik yang tidak mempengaruhi glandula saliva menghasilkan glukosa. ${ }^{6}$

Pada penelitian ini juga ditemukan spora dan hifa Candida pada sampel yang diteliti. Kolonisasi Candida dalam rongga mulut merupakan keadaan normal dengan prevalensi C.albicans berkisar antara $20-40 \%$. Pada pasien DM, prevalensi kolonisasi $C$. albicans meningkat mencapai $80 \%{ }^{9}$

Beberapa penelitian tentang kondisi DM dengan kadar glukosa saliva yang meninggi mempengaruhi kolonisasi C.albicans. Pendapat Minasari ${ }^{9}$ mengutip Darwazeh pertumbuhan C.albicans meningkat pada pasien DM disebabkan kadar glukosa saliva yang tinggi. Soenartyo juga melaporkan bahwa makanan yang kaya karbohidrat memudahkan pertumbuhan koloni C.albicans yang menyebabkan kandidiasis. Pernyataan ini didukung data hasil penelitian in vitro yang dilaksanakan Samaranayake pada saliva yang disuplai glukosa dapat meningkatkan pertumbuhan kolonisasi C.albicans. ${ }^{9}$

Berdasarkan hasil penelitian tentang korelasi kadar glukosa saliva dengan glukosa darah terhadap terjadinya kandidiasis oral pada pasien diabetes melitus, disimpulkan bahwa kadar glukosa saliva yang tinggi diikuti kadar glukosa darah yang tinggi; Peningkatan kadar glukosamempengaruhi terjadinya kandidiasis oral pada pasien DM.

\section{DAFTAR PUSTAKA}

1. Tiara OS, Hayu QZ, Bramita BA. Saliva: biofluid alternatif untuk deteksi dini penyakit sistemik. BIMKES 2014; 1-17

2. Satish BN, Srikala P, Maharudrappa B, Awanti SM, Kumar P, Hugar D. Saliva: a tool in assessing glucose levels in diabetes mellitus. J Int Oral Health 2014; 6(2): 114-7

3. Mithra NH, Divya T, Shilpa SS, Darshana D. Salivary electrolyte as a biomarker in caries active tipe II diabetes-a comparative study. NUJHS 2014; 4(3): 85-9

4. Ana CU, Maria SM, Paulo CA, Teresa CS. Comparative study of the concentration of salivary and blood glucose in type 2 diabetic patients. J Oral Sci 2010; 25(2): 293-8

5. Greenberg MS, Glick M, Ship JA. Burket's oral medicine $11^{\text {th }}$ Ed. New Delhi: BC Decker Inc; 2008. pp.78-82

6. Arasi SP. Correlation of salivary glucose level with blood glucose level in diabetes mellitus. J Oral Maxillofac Res 2012; 3(3): 1-7

7. Preethi B, Subhas GB, Kumari NS, Shishir RS, Anusha LR, Renita LC, et al. Can saliva offer an advantage in monitoring of diabetes mellitus? A case control study. J Clin Exp Dent 2014; 6(4): e335-8

8. Abikshyeet P, Ramesh V, Oza N. Glucose estimation in the salivary secretion of diabetes mellitus patients. Dove Medical Press; 2012; 5: 149-54

9. Minasari N. Kandidiasis rongga mulut dan diabetes melitus. Majalah Kedokteran Nusantara 2008; 41(3): 200-6 